\title{
Impact of CNS Diseases on Drug Delivery to Brain Extracellular and Intracellular Target Sites in Human: A "WHAT-IF" Simulation Study
}

\author{
Mohammed A. A. Saleh (D) and Elizabeth C. M. de Lange *(D) \\ Division of Systems Biomedicine and Pharmacology, Leiden Academic Center for Drug Research, \\ Leiden University, 2333 CC Leiden, The Netherlands; m.a.a.e.w.saleh@lacdr.leidenuniv.nl \\ * Correspondence: ecmdelange@lacdr.leidenuniv.nl
}

check for

updates

Citation: Saleh, M.A.A.; de Lange, E.C.M. Impact of CNS Diseases on Drug Delivery to Brain Extracellular and Intracellular Target Sites in Human: A "WHAT-IF" Simulation Study. Pharmaceutics 2021, 13, 95. https://doi.org/10.3390/ pharmaceutics13010095

Received: 29 November 2020 Accepted: 8 January 2021 Published: 13 January 2021

Publisher's Note: MDPI stays neutral with regard to jurisdictional clai$\mathrm{ms}$ in published maps and institutional affiliations.

Copyright: $\odot 2021$ by the authors. Licensee MDPI, Basel, Switzerland. This article is an open access article distributed under the terms and conditions of the Creative Commons Attribution (CC BY) license (https:// creativecommons.org/licenses/by/ $4.0 /)$.

\begin{abstract}
The blood-brain barrier (BBB) is equipped with unique physical and functional processes that control central nervous system (CNS) drug transport and the resulting concentration-time profiles (PK). In CNS diseases, the altered BBB and CNS pathophysiology may affect the CNS PK at the drug target sites in the brain extracellular fluid (brain $\mathrm{ECF}_{\text {) }}$ and intracellular fluid (brain $\mathrm{ICF}_{\text {) }}$ that may result in changes in CNS drug effects. Here, we used our human CNS physiologically-based PK model (LeiCNS-PK3.0) to investigate the impact of altered cerebral blood flow (CBF), tight junction paracellular pore radius (para radius ), brain ECF $_{\text {volume, and } \mathrm{pH} \text { of brain }} \mathrm{ECF}\left(\mathrm{pH}_{\mathrm{ECF}}\right.$ ) and of brain $\mathrm{iCF}_{\mathrm{I}}$ $\left(\mathrm{pH}_{\mathrm{ICF}}\right)$ on brain $\mathrm{ECF}$ and brain ICF PK for 46 small drugs with distinct physicochemical properties. LeiCNS-PK3.0 simulations showed a drug-dependent effect of the pathophysiological changes on the rate and extent of $\mathrm{BBB}$ transport and on brain $\mathrm{ECF}_{\mathrm{E}}$ and brain $\mathrm{ICF}_{\mathrm{CK}} \mathrm{PK}$. Altered para radius $_{\mathrm{CH}} \mathrm{pH}_{\mathrm{ECF}}$, and $\mathrm{pH}_{\mathrm{ICF}}$ affected both the rate and extent of $\mathrm{BBB}$ drug transport, whereas changes in $\mathrm{CBF}$ and brain $_{\mathrm{ECF}}$ volume modestly affected the rate of BBB drug transport. While the focus is often on BBB paracellular and active transport processes, this study indicates that also changes in $\mathrm{pH}$ should be considered for their important implications on brain $\mathrm{ECF}_{\text {and }}$ brain ICF $_{\text {target site }}$ PK.
\end{abstract}

Keywords: blood-brain barrier; passive transport; CNS diseases; brain pharmacokinetics

\section{Introduction}

Both the rate and extent of central nervous system (CNS) unbound drug transport determine CNS concentration-time profiles of the unbound drug (PK) [1]. PK at the CNS target sites in the brain extracellular fluid (brain ${ }_{\mathrm{ECF}}$ ) and brain intracellular fluid (brain ICF ) is a function of plasma PK, drug transport across the blood-brain barrier (BBB), and intra-brain distribution. Such PK processes result from the combination of the drug physicochemical properties and the physiological characteristics of the CNS $[2,3]$.

The BBB lies at the brain microvessels, including brain capillaries and their direct surroundings [2]. The BBB has physical properties that reduce passive drug transport across the BBB for hydrophilic and large molecules, i.e., by the presence of the tight junctions between the brain microvascular endothelial cells. In addition, pericytes and astrocyte end feet ensure a complete coverage of the brain microvascular endothelial cells, while the basement membrane surrounds the endothelial cells and pericytes, separating them from each other and from the astrocytes end feet. All together, these cells ensure the physical integrity of the BBB against the foreign plasma molecules. The BBB also has active efflux and influx transporters, pinocytosis, transcytosis, and metabolic enzymes, which are all powered with energy supplied by the large mitochondrial count. The brain tissue composition and active cellular membrane transporters further determine the unbound drug PK in the different brain compartments, while different $\mathrm{pH}$ values of the CNS compartments govern, for acids and bases, the extent of ionization [2]. 
CNS disease pathophysiology may result in altered (unbound) brain PK, as has been shown, for example, for traumatic brain injury [4,5], epilepsy [6], and brain tumors [7]. The brain $_{\mathrm{ECF}}$ and brain $\mathrm{ICF}$ unbound PK govern the CNS drug effects; therefore, understanding the impact of pathophysiological changes associated with CNS diseases on brain PK target sites is indispensable.

While being a very important parameter, $\mathrm{Kp} \mathrm{uu}_{\mathrm{u}, \mathrm{BBB}}$ is a measure for the extent (at equilibrium) but not the rate of drug transport. However, for drug effects, also the profile of concentrations seems of importance [8], i.e., having the right concentration, for the right duration, at the right site. Therefore, CNS drug development should consider the effect of both the rate and extent of BBB drug transport and of intra-brain distribution processes on the target site PK, and as indicated above, these processes may be influenced in CNS disease conditions.

Physiologically-based pharmacokinetic (PBPK) modeling [9] has provided important insights in what governs PK at different CNS sites in health [10] and in disease [11]. PBPK models use a system of ordinary differential equations to predict the rate of change of drug concentration in each physiological compartment. Importantly, PBPK models are mechanistic and explicitly distinguish between physiological body compartment characteristics (such as tissue volume, blood flow, etc.) and drug properties (such as molecular weight, lipophilicity, $\mathrm{pk}_{\mathrm{a}}$, etc.). Body organs and tissues are mathematically represented as compartments with their physiological volumes, and these are connected to the central blood circulation by their physiological blood flows. Physiological processes involved in drug transport and disposition such as active transport, metabolism, tissue non-specific binding, etc. are mechanistically included. Given their mechanistic nature, PBPK models allow the translation between species and between populations and the exploration of different virtual scenarios, i.e., what-if scenarios.

The "Leiden CNS PBPK predictor v3.0" or LeiCNS-PK3.0 (Figure 1 and Figure S1 in Supplementary Materials) is a CNS PBPK model that adequately predicts the PK of small drug molecules in the CNS of rats and humans on the basis of exclusively plasma PK, drug physicochemical, CNS physiological, and in vitro information $[10,12,13]$. The LeiCNS-PK3.0 model accounts for the different CNS physiological compartments such as the brain microvasculature, brain ICF $_{\text {and }}$ brain $_{\mathrm{ECF}}$, lysosomes, and cerebrospinal fluid (CSF) compartments (such as lateral ventricles, third and fourth ventricles, cisterna magna, and subarachnoid space, including the lumbar CSF region). Different drug transport modes within the CNS are represented including drug transport by paracellular, transcellular, and active transport across the BBB and blood-CSF barrier (BCSFB) and by bulk fluid flow from

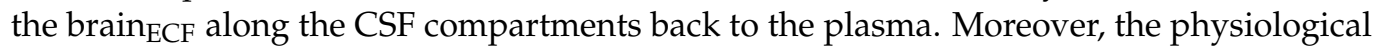
processes that affect intra-brain unbound drug distribution are accounted for, such as brain tissue non-specific binding and the effect of CNS pH on drug ionization.

In general, changes in BBB properties and CNS physiology are common in CNS diseases, as well as in aging or other conditions, but the impact of some of these processes is often overlooked when investigating brain PK in such conditions. These include brain ECF volume, of which the fraction is doubled during sleep and anesthesia [14] and declines with aging [15]; the BBB tight junctions' paracellular pore radius (para radius $_{\text {) that increases }}$ for example in Alzheimer's disease [16], with aging [17], and in traumatic brain injury [18]; CBF that declines for example in Alzheimer's disease [19], with aging [20], and anesthesia [21]; and $\mathrm{pH}_{\mathrm{ECF} / \mathrm{ICF}}$ that declines for example in traumatic brain injury [22], brain ischemia [23,24], and with aging [25].

In this paper, we use LeiCNS-PK3.0 to explore the effect of the pathophysiological changes of: $\mathrm{CBF}$, para ${ }_{\text {radius }}$, brain $\mathrm{ECF}_{\text {volume, }} \mathrm{pH}_{\mathrm{ECF}}$, and $\mathrm{pH}_{\mathrm{ICF}}$ on $\mathrm{BBB}$ transport and intra-brain distribution of 46 small drugs of different physicochemical properties. 


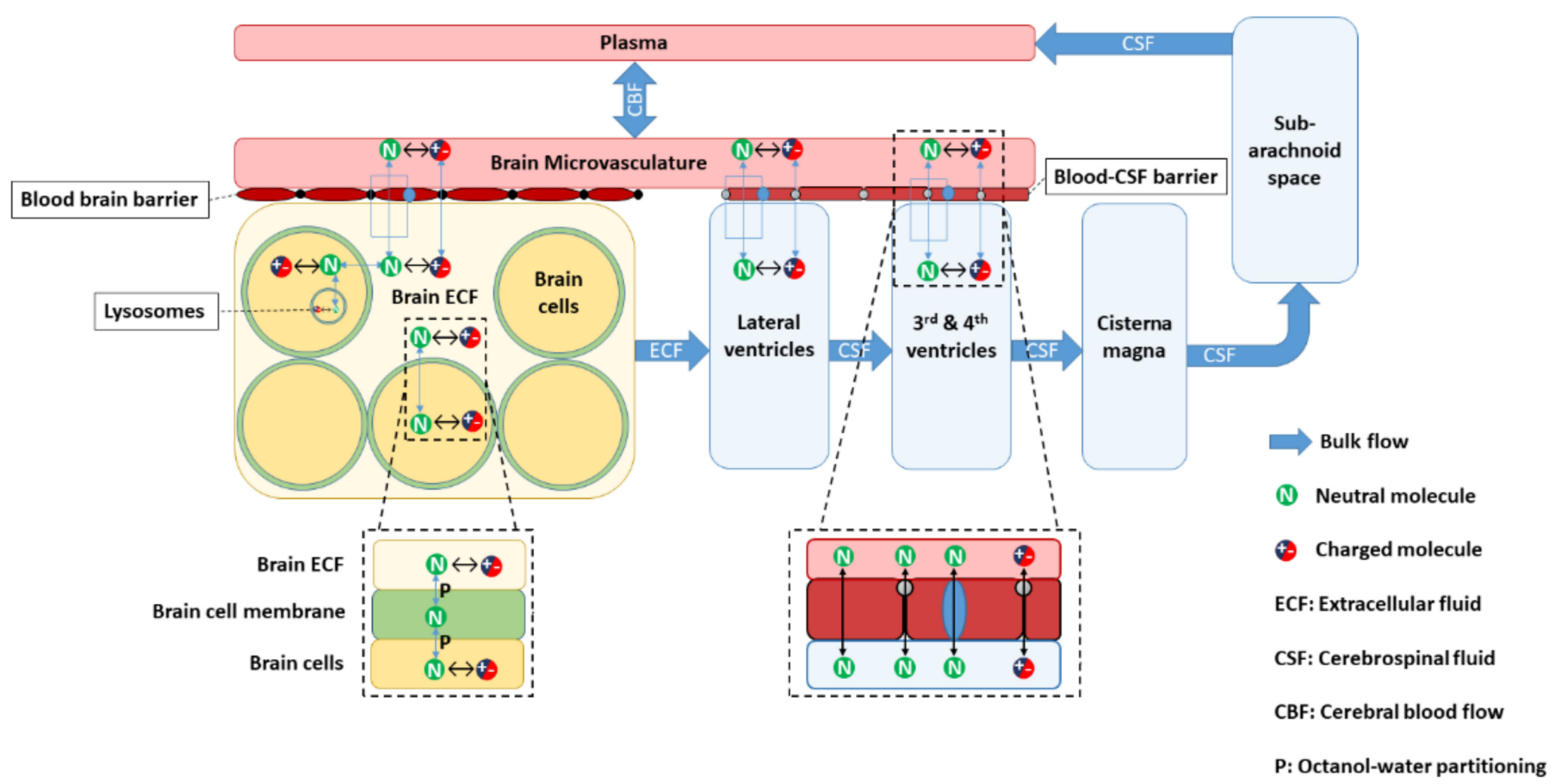

Figure 1. LeiCNS-PK3.0 model structure. The central nervous system (CNS) model connects to the plasma via cerebral blood flow. LeiCNS-PK3.0 accounts for the brain and cerebrospinal fluid (CSF) compartments, the presence of the blood-brain barrier (BBB) and blood-CSF barriers, drug transport across the barriers and within the CNS, and physiological process such as non-specific binding and the effect of $\mathrm{pH}$ on drug ionization and on its passive transport.

\section{Materials and Methods}

\subsection{LeiCNS-PK3.0 Model}

This simulation study was performed using LeiCNS-PK3.0 (Figure 1 and Figure S1 in Supplementary Materials) and human CNS physiological parameters (Table 1) [12]. A virtual one-compartment plasma PK model was used as input to the CNS model, with plasma clearance of $297 \mathrm{~L} / \mathrm{h}$ and a central compartment volume of $108 \mathrm{~L}$. The drug dose was $1 \mathrm{~g}$, which was administered as intravenous infusion over $15 \mathrm{~min}$. The fixed plasma PK model and dosing regimen were used for all investigated drugs, thus solely focusing

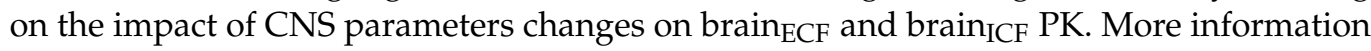
on the model buildup and the associated equations can be found at $[10,12,13]$.

\subsection{Drug Parameters}

The physicochemical properties of the 46 small drugs (Table 2 and Table S1) in this study were available from the Drugbank database release version 5.1.7 (go.drugbank.com) [26]. These drugs have distinct physicochemical properties such as molecular weight (Mwt: $150-500 \mathrm{~g} / \mathrm{mol}$ ), lipophilicity ( $\log \mathrm{P}:-3.7-4.3)$, acid/base ionization constants $\left(\mathrm{pk}_{\mathrm{a}}\right.$ : $\left.3-16 / \mathrm{pk}_{\mathrm{b}}:-9-10\right)$ and different affinities to active transporters. We included calculated $\mathrm{pk}_{\mathrm{a} / \mathrm{b}}$ values from CHEMAXON [27] and included calculated lipophilicity from the ALOGPS method [28], unless experimental octanol-water portioning values were reported. 
Table 1. Human CNS physiological parameters used in LeiCNS-PK3.0.

\begin{tabular}{|c|c|c|c|c|}
\hline \multicolumn{2}{|c|}{ Parameter } & Value & Range & Reference \\
\hline \multirow{9}{*}{$\begin{array}{l}\text { Volumes } \\
\quad(\mathrm{mL})\end{array}$} & Total brain & 1250 & $1110-1380$ & {$[47-50]$} \\
\hline & $\begin{array}{l}\text { Brain extracellular fluid } \\
\text { (brain } \\
\text { ECF })\end{array}$ & $253^{1}$ & $217-300$ & [51-55] \\
\hline & $\begin{array}{l}\text { Brain intracellular fluid } \\
\left.\text { (brain }_{\mathrm{ICF}}\right)\end{array}$ & 10001 & & calculated \\
\hline & Brain cell lysosomes $\left(\mathrm{V}_{\mathrm{LYS}}\right)$ & $12.5^{2}$ & & [56] \\
\hline & Brain microvasculature & $45^{3}$ & $37-50$ & {$[53,57,58]$} \\
\hline & Lateral ventricles & 20 & $11-16$ & [59-63] \\
\hline & 3rd and 4th ventricles & 3 & $2.3-3.7$ & {$[61,62]$} \\
\hline & Cisterna magna & 1 & & {$[64]$} \\
\hline & Subarachnoid space & 116 & $110-116$ & [65-67] \\
\hline \multirow{3}{*}{$\begin{array}{c}\text { Flows } \\
(\mathrm{mL} / \mathrm{min})\end{array}$} & Cerebral blood flow (CBF) & 689 & $644-722$ & {$[68-70]$} \\
\hline & Brain ECF bulk flow & $0.2^{4}$ & & [71] \\
\hline & CSF flow & 0.42 & $0.28-0.68$ & {$[67,72-75]$} \\
\hline \multirow{4}{*}{$\begin{array}{l}\text { Surface areas } \\
\qquad\left(\mathrm{cm}^{2}\right)\end{array}$} & Blood-brain barrier $\left(\mathrm{SA}_{\mathrm{BBB}}\right)$ & 150,000 & $140 \times 10^{3}-360 \times 10^{3}$ & [76-84] \\
\hline & Blood CSF barrier (SA $\mathrm{BCSFB})$ & $15,000^{5}$ & & {$[85,86]$} \\
\hline & Brain cell membrane $\left(\mathrm{SA}_{\mathrm{BCM}}\right)$ & $2,666,520^{6}$ & & {$[87,88]$} \\
\hline & Lysosomes membrane & $1,980,260^{7}$ & & [89-93] \\
\hline \multirow{2}{*}{$\begin{array}{l}\text { Width } \\
(\mu \mathrm{m})\end{array}$} & Blood brain barrier & \multirow{2}{*}{0.5} & \multirow{2}{*}{$0.2-0.4$} & \multirow{2}{*}[81,94]{} \\
\hline & Blood CSF barrier & & & \\
\hline Number & Total brain cells $\left(\mathrm{N}_{\mathrm{br}, \mathrm{cells}}\right)$ & $1.71 \times 10^{118}$ & & {$[87,88]$} \\
\hline \multirow{2}{*}{$\begin{array}{l}\text { Paracellular pore } \\
\text { radius } \\
(\mu \mathrm{m})\end{array}$} & $\begin{array}{c}\text { Blood-brain barrier } \\
\left.\text { (para }{ }_{\text {radius }}\right)\end{array}$ & 0.0007 & $0.0007-0.0009$ & {$[10,13,95,96]$} \\
\hline & Blood CSF barrier & 0.0027 & & {$[10,13,95]$} \\
\hline \multirow{4}{*}{$\begin{array}{l}\text { Effective surface area } \\
\qquad(\%)\end{array}$} & BBB Transcellular transport & 99.8 & & \multirow{2}{*}[13,97,98]{} \\
\hline & BCSFB Transcellular transport & 99.8 & & \\
\hline & BBB paracellular transport & $0.004^{9}$ & & \multirow{2}{*}[10,95]{} \\
\hline & BCSFB paracellular transport & $0.016^{9}$ & & \\
\hline \multirow{5}{*}{$\mathrm{pH}$} & Plasma and brain MV & 7.4 & & [99] \\
\hline & $\begin{array}{l}\text { Brain extracellular fluid } \\
\qquad\left(\mathrm{pH}_{\mathrm{ECF}}\right)\end{array}$ & 7.3 & & [100] \\
\hline & Cerebrospinal fluid & 7.3 & & [101] \\
\hline & Brain cells $\left(\mathrm{pH}_{\mathrm{ICF}}\right)$ & 7 & & [100] \\
\hline & Brain cell lysosomes & 5 & & [100] \\
\hline
\end{tabular}

${ }^{1}$ Volume ratio of Brain ${ }_{\mathrm{ECF}}$ :Brain $\mathrm{ICF}$ is 1:4. ${ }^{2}$ Calculated as $1.25 \%(1 / 80)$ of brain ${ }_{\mathrm{ICF}}$ volume; based on liver lysosomes. ${ }^{3}$ Calculated as $3.67 \%$ of total brain volume. ${ }^{4}$ Assumed as $50 \%$ of CSF bulk flow. ${ }^{5} \mathrm{SA}_{\mathrm{BCSFB}}=0.1 * \mathrm{SA}_{\mathrm{BBB}}$. $\mathrm{SA}_{\mathrm{BCSFB}}$ at LV (and TFV) is assumed $50 \%$ of $\mathrm{SA}_{\mathrm{BCSFB}} \cdot{ }^{6} \mathrm{SA}_{\mathrm{BCM}}=\mathrm{SA}_{\text {cell }}{ }^{*} \mathrm{~N}_{\mathrm{br}, \text { cells }}$. Radius ${ }_{\mathrm{br}, \text { cell }}$ was calculated with Brain $\mathrm{ICF}$ volume and $\mathrm{N}_{\mathrm{br}, \text { cells, }}$, assuming spherical cells. ${ }^{7}$ Based on $\mathrm{V}_{\mathrm{LYS}}$ and mean radius of lysosomes in monkey kidney, rat kidney, and rat neuronal cell $(0.1875 \mu \mathrm{m}) .{ }^{8}$ Based on 1500 gm brain. ${ }^{9}$ Based on an endothelial cell perimeter of $17 \mu \mathrm{m}$.

Active transport across the BBB was described using $\mathrm{Kp} \mathrm{uu}_{\mathrm{u}, \mathrm{BBB}}$ values (Table 2 and Table S1), which were calculated from rat microdialysis plasma and brain ECF $_{\text {drug concen- }}$ trations [12,29-31]. Then, these were translated to predict human BBB active transport as described in [10], taking into consideration the interspecies difference in protein expression [32-36] of the four main BBB active transporters: P-glycoprotein ( $\mathrm{p}$-gp), multi-drug- 
resistant protein-4 (MRP4), breast cancer resistance protein (BCRP), and organic anionic transporter 3 (OAT3). The protein expression of other relevant transporters at the BBB such as MRP1 was assumed the same in rats and humans, due to the absence of quantitative information on the difference of protein expression in rats and in humans [32-37]. Information on drugs affinity to a certain transporter was available from Drugbank [26]. The factors used for the rat-to-human translation are summarized in Table S2. Differences in transporters functionality, which is distinct of expression [38], in rats and humans [39-41] were not accounted for. This interspecies difference is not attributed to the transporter per se, but rather to the combination of the drug and the transporter. Given both the scarcity of transporter functionality information in the literature and the goal of the current study, rat-to-human translation was based on differences in expression only. Kp $\mathrm{puu}_{\text {,BCSFB values }}$ (Table 2 and Table S1), which represent active transport across the BCSFB, were either available from the literature or assumed the same as $\mathrm{Kp} \mathrm{uu}_{\mathrm{uBB}}$.

\subsection{Selection of Pathophysiological Parameters Values}

The CNS parameters investigated in this study were CBF, para radius, $_{\text {Brain }}$ ECF volume, $\mathrm{pH}_{\mathrm{ECF}}$, and $\mathrm{pH}$ ICF. The changes in the parameters values were selected to reflect their values in CNS diseases. Parameters were changed based on literature values as follows: CBF by $70 \%$ [42] and 150\% [21]; para radius $_{\text {by } 50 \% \text { and } 500 \% \text { [43]; brain }}$ ECF volume by $70 \%$ and $150 \%[14,15] ; \mathrm{pH}_{\mathrm{ECF}}$ to 5 and 8 [23]; and $\mathrm{pH}_{\mathrm{ICF}}$ to 6 and $7.6[24,44]$.

\subsection{LeiCNS-PK3.0 Simulations and Data Analysis}

LeiCNS-PK3.0 simulations were observed over $600 \mathrm{~min}$ for all drugs. For low transcel-

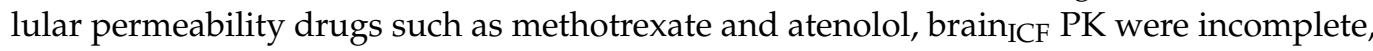
i.e., it had not reached $C_{\max }$ after $600 \mathrm{~min}$, and the observation time was extended to 20,000 min (results not shown). LeiCNS-PK3.0 simulations were performed using RxODE version 0.9.2-0 [45] using LSODA (Livermore Solver for Ordinary Differential Equations) Fortran package and $\mathrm{R}$ version 4.0 .3 [46].

Table 2. Physicochemical properties, active transporters affinities, and BBB transport clearances of selected drugs.

\begin{tabular}{|c|c|c|c|c|c|c|c|c|c|c|c|c|c|c|c|}
\hline Drug & Mwt & $\log P$ & Drug Ion Class & $\mathrm{pk}_{\mathrm{a}}$ & $\mathrm{pk}_{\mathrm{b}}$ & Kp $p_{u, E C F}$ & $K p_{u u, L V}$ & $\mathrm{Kp}_{\mathrm{uu}, \mathrm{CM}}$ & BCRP & $p-g p$ & OAT3 & MRP4 & $\mathrm{CL}_{\mathrm{p}}$ & $\mathrm{CL}_{\mathrm{T}, \mathrm{ef}}$ & $\mathrm{CL}_{\mathrm{T}, \mathrm{in}}$ \\
\hline Caffeine & 194.2 & -0.07 & Neutral & $\mathrm{NA}$ & -0.92 & $0.96^{1}$ & 0.961 & 0.961 & $X$ & - & - & - & $\begin{array}{l}\mathrm{r} \\
48.9\end{array}$ & $\begin{array}{l}1, \mathrm{el} \\
4.28\end{array}$ & 2.38 \\
\hline Cephalexin & 347.4 & 0.65 & Zwitterion & 3.26 & 7.23 & 0.0151 & 0.0151 & 0.0151 & - & - & $x$ & - & 37.4 & 2736 & $<0.01$ \\
\hline Codeine & 299.4 & 1.39 & Base & 13.8 & 9.19 & 11 & 11 & 11 & - & - & - & - & 40.1 & 0.71 & 0.89 \\
\hline Gabapentin & 171.2 & 1.25 & Zwitterion & 4.63 & 9.91 & 0.131 & 0.131 & 0.131 & - & - & - & - & 51.9 & 347 & $<0.01$ \\
\hline Genistein & 270.2 & 3.04 & Acid & 6.55 & -5.3 & 0.041 & 0.041 & 0.041 & $x$ & $x$ & - & - & 42.3 & 1557 & 245 \\
\hline Levetiracetam & 170.2 & -0.64 & Neutral & 16.1 & -1.6 & 0.311 & 0.311 & 0.311 & - & $x$ & - & $x$ & 52.0 & 3.73 & 0.69 \\
\hline Morphine & 285.3 & 0.87 & Base & 10.3 & 9.12 & $0.23^{2}$ & 0.232 & 0.232 & - & $x$ & - & - & 41.0 & 30.2 & 0.34 \\
\hline Thiopental & 242.3 & 2.85 & Acid & 7.2 & -3 & 0.91 & 0.91 & 0.91 & - & - & - & - & 44.2 & 569 & 508 \\
\hline
\end{tabular}

${ }^{1}$ [29]; ${ }^{2}$ [12]; Mwt: molecular weight $(\mathrm{g} / \mathrm{mol}) ; \log \mathrm{P}$ : octanol-water partition coefficient; $\mathrm{pk}_{\mathrm{a}}$ : acid dissociation coefficient; $\mathrm{pk}_{\mathrm{b}}$ : base dissociation coefficient; $\mathrm{CL}_{\mathrm{T}, \mathrm{e}}$ : transcellulr efflux clearance (in $\mathrm{mL} / \mathrm{min}$ ) at $\mathrm{BBB} ; \mathrm{CL}_{\mathrm{T}, \text { in }}$ : transcellulr influx clearance (in $\mathrm{mL} / \mathrm{min}$ ) at $\mathrm{BBB}$; $\mathrm{CL}_{\mathrm{P}}$ : paracellular passive BBB clearance (in $\mathrm{mL} / \mathrm{min}$ ); $\mathrm{X}$ : active transporter substrate; $\mathrm{p}$-gp: P-glycoprotein, MRP4: multi-drug-resistant protein-4, BCRP: breast cancer resistance protein, OAT3: organic anionic transporter- 3 . $\mathrm{CL}_{\mathrm{T}, \mathrm{e}}, \mathrm{CL}_{\mathrm{T}, \mathrm{in}}$, and $\mathrm{CL}_{\mathrm{P}}$ are calculated as described in $[12,13]$.

LeiCNS-PK3.0 simulation results were evaluated by comparing the different PK at

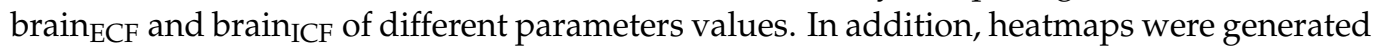
to reflect the magnitude of change of $C_{\max }, \mathrm{T}_{\max }, \mathrm{AUC}_{0-\mathrm{T}}, \mathrm{Kp}_{\mathrm{uu}, \mathrm{BBB}}$, and $\mathrm{Kp}_{\mathrm{uu} \text {,cell. }} \mathrm{AUCs}$ were calculated using the R package PKNCA version 0.9.4.

$\mathrm{K} \mathrm{puu}_{\mathrm{u}, \mathrm{BBB}}$ and $\mathrm{Kp}$ uu,cell were calculated as follows [1]:

$$
\begin{aligned}
& \mathrm{Kp} \mathrm{uu}, \mathrm{BBB}=\frac{\mathrm{AUC}_{0-\infty, \mathrm{ECF}}}{\mathrm{AUC}_{0-\infty, \mathrm{MV}}} \\
& \mathrm{Kp}_{\mathrm{uu}, \mathrm{cell}}=\frac{\mathrm{AUC}_{0-\infty, \mathrm{ICF}}}{\mathrm{AUC}_{0-\infty, \mathrm{ECF}}}
\end{aligned}
$$


For $\mathrm{AUC}_{0-\infty}$, the elimination rate constant was calculated from the terminal elimination phase and was used to extrapolate the concentration-time curve to time infinity.

Two-fold change was calculated to reflect the effect of changing one parameter on PK parameters; a value of 1 reflects a two-fold change.

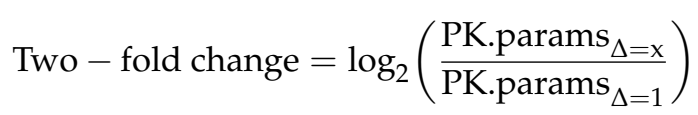

where PK.params $s_{\Delta=x}$ and PK.params $s_{\Delta=1}$ represent the calculated PK parameters $\left(\mathrm{C}_{\max }\right.$, $\mathrm{T}_{\max }, \mathrm{AUC}_{0-\mathrm{T}}, \mathrm{Kp}_{\mathrm{uu}, \mathrm{BBB}}$, and $\left.\mathrm{Kp}_{\mathrm{uu}, \text { cell }}\right)$ at $\mathrm{x}$-fold altered and physiological CNS parameters, respectively.

\section{Results}

The simulated impact of pathophysiological changes of $\mathrm{CBF}$, para radius, $_{\text {, }}$ brain $\mathrm{ECF}$ volume, $\mathrm{pH}_{\mathrm{ECF}}$, and $\mathrm{pH}_{\mathrm{ICF}}$ on $\mathrm{PK}$ at brain $\mathrm{ECF}_{\mathrm{EF}}$ and brain $\mathrm{ICF}_{\mathrm{ICF}}$ are displayed for selected drugs in Figure 2 and for all drugs in Figure S2. The associated heatmaps, Figure 3 and Figure $\mathrm{S} 3$, reflect the changes in the $\mathrm{BBB}$ drug transport rate via $\mathrm{C}_{\max }$, and $\mathrm{T}_{\max }$ and extent via $\mathrm{AUC}_{0-\mathrm{T}}, \mathrm{Kp}_{\mathrm{uu}, \mathrm{BBB}}$, and $\mathrm{Kp}_{\mathrm{uu}, \text { cell }}$. As plasma PK was fixed, any role of plasma in the

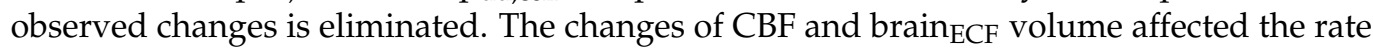
but not the extent of $\mathrm{BBB}$ drug transport, whereas changes in $\mathrm{pH}_{\mathrm{ECF}}, \mathrm{pH}_{\mathrm{ICF}}$, and para ${ }_{\text {radius }}$ affected both the rate and extent of BBB drug transport.

\subsection{Increased Passive Transport via Widened Para radius}

Figures 2 and 3 (2nd column) demonstrate that the impact of a changed para radius $_{\text {s }}$ on BBB drug passive transport varied according to the drug lipophilicity, ionization at physiological $\mathrm{pH}$, and affinity to active transporters. Of interest, a five-fold increase in para $_{\text {radius }}$ resulted in a decrease in the extent of BBB transport of risperidone, paliperidone, and omeprazole, as demonstrated by a decrease in $\mathrm{AUC}_{0-\mathrm{T}, \mathrm{ECF}}$ and in $\mathrm{Kp}_{\mathrm{uu}, \mathrm{BBB}}$.

\section{2. $p H_{E C F}$ and $p H_{I C F}$ are Key Factors of Drug Distribution in Brain ${ }_{E C F}$ and Brain ${ }_{I C F}$}

Figures 2 and 3 (4th and 5th columns) show the influence of $\mathrm{pH}$ changes on the rate and extent of drug transport across the BBB and across the brain cell membranes. A pH increase in a given compartment generally resulted in a faster rate and increased the extent of acidic drug transport and a slower rate and decreased the extent of the basic drug transport into that compartment, and vice versa. The rate and extent of drug transport in the adjacent compartment were affected in an inverse fashion. For amphoteric drugs, the effect of $\mathrm{pH}$ on their transport rate and extent was relative to the ionization constants of their strongest acidic and basic groups. As expected, $\mathrm{pH}$ changes had no effect on drugs that are neutral at the physiological $\mathrm{pH}$ range.

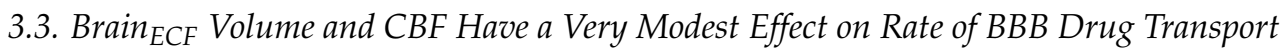

Figure 3 (1st and 3rd columns) display only a $\mathrm{T}_{\max }$ increase of $<50 \%$ associated with a $50 \%$ increase of brain ${ }_{\mathrm{ECF}}$ volume, while a slight $\mathrm{T}_{\max }$ decrease of $<25 \%$ was noticed with a $30 \%$ decrease of brain ${ }_{\mathrm{ECF}}$ volume. With regard to $\mathrm{CBF}$, a $30 \%$-decrease resulted in a $<50 \%$-delay of $\mathrm{T}_{\max }$, whereas a $50 \%$-increase resulted in a $<25 \%$-earlier $\mathrm{T}_{\max }$. These effects were associated with neutral drugs of relatively higher net BBB influx. 


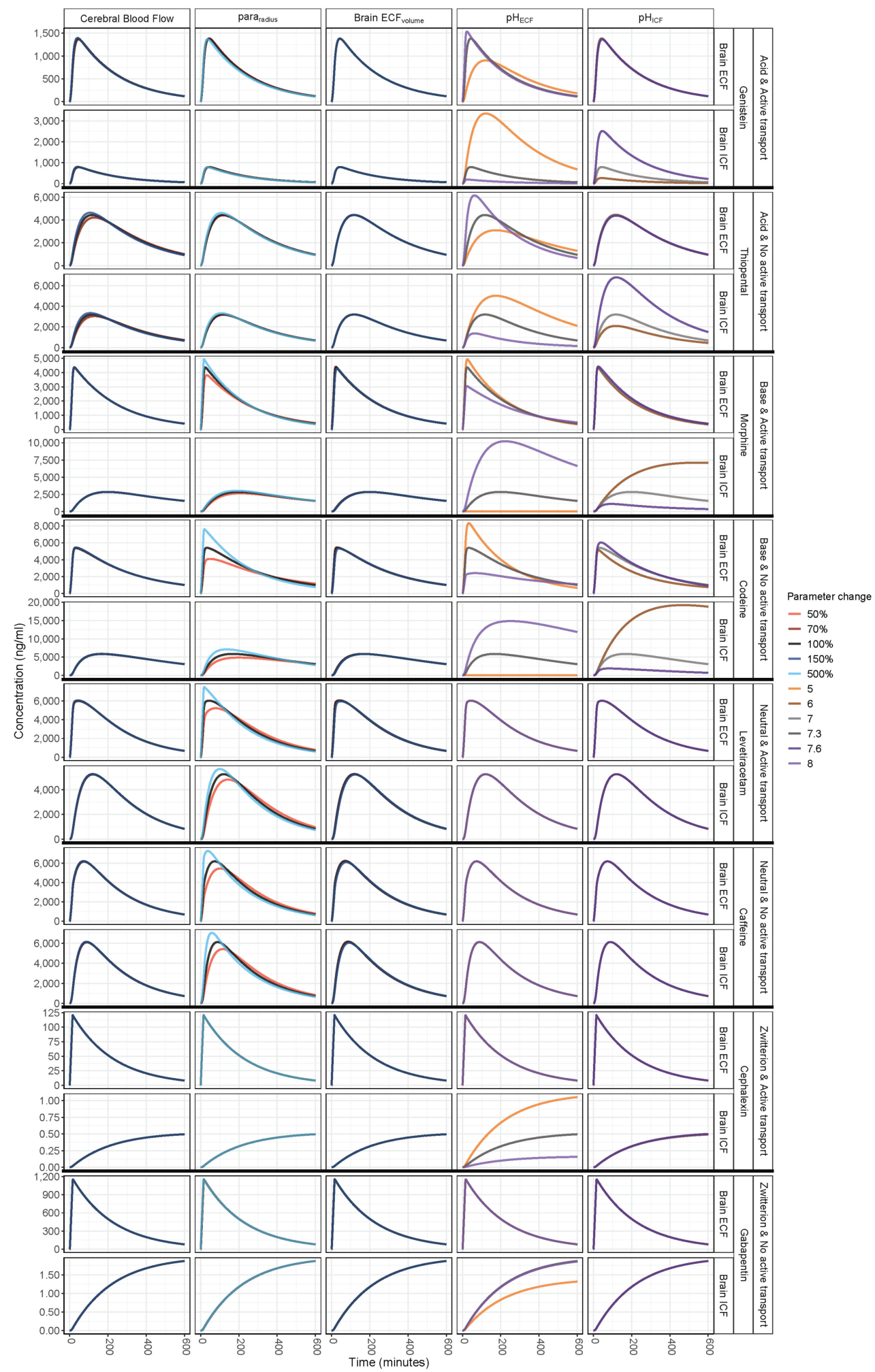

Figure 2. Simulated concentration-time profiles of selected drugs at physiological and pathophysiological values of CBF, tight junction paracellular pore radius ( para $_{\text {radius }}$ ), brain ECF $_{\text {volume, }} \mathrm{pH}_{\mathrm{ECF}}$, and $\mathrm{pH}_{\mathrm{ICF}}$. Para radius $_{\text {affected the rate and }}$ extent of passive drug transport across the $\mathrm{BBB}, \mathrm{pH}_{\mathrm{ECF}}$ and $\mathrm{pH}_{\mathrm{ICF}}$ affected the brain $\mathrm{ECF}_{\mathrm{E}}$ and brain $\mathrm{ICF}_{\mathrm{C}}$ unbound drug

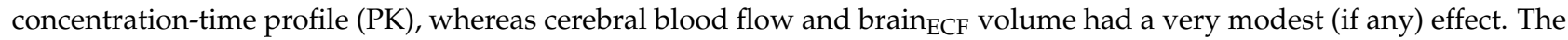
fixed plasma PK used excludes the involvement of plasma PK in the observed changes. 


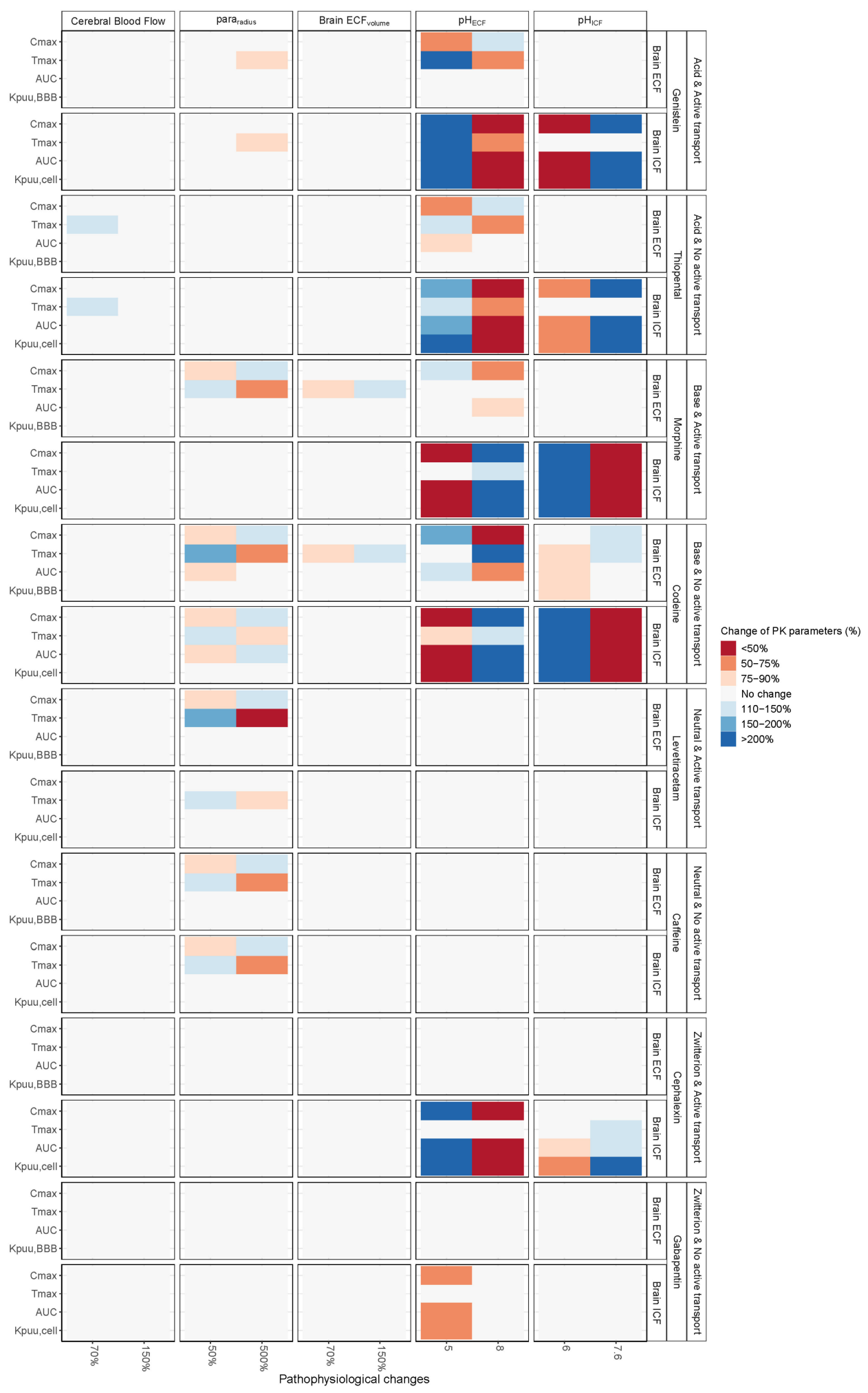

Figure 3. Heatmaps summarizing the effect of pathophysiological changes of $\mathrm{CBF}$, tight junction paracellular pore radius ( para $_{\text {radius }}$ ), brain $\mathrm{ECF}_{\text {volume, }} \mathrm{pH}_{\mathrm{ECF}}$, and $\mathrm{pH}_{\mathrm{ICF}}$ on brain pharmacokinetic parameters: $\mathrm{C}_{\max }, \mathrm{T}_{\max }, \mathrm{AUC}, \mathrm{Kp} \mathrm{puu}_{\mathrm{ECF}}$, and $\mathrm{Kp}_{\text {uu,cell }} \cdot \mathrm{C}_{\max }$ and $\mathrm{T}_{\max }$ define the rate of BBB drug transport, while AUC and Kpuu define the extent of drug transport. Effect of pathophysiological changes remain drug (class) specific. Similar to the concentration-time profiles, para $\mathrm{radius}$ $\mathrm{pH}_{\mathrm{ECF}}$, and $\mathrm{pH}$ ICF had a profound effect on brain pharmacokinetics compared to the minor effect of cerebral blood flow

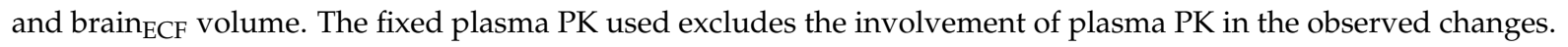




\section{Discussion}

LeiCNS-PK3.0 simulations have demonstrated the drug-dependent effect of patho-

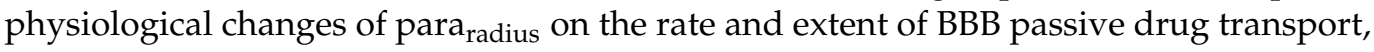
and of $\mathrm{pH}_{\mathrm{ECF}}$ and $\mathrm{pH}_{\mathrm{ICF}}$ on the PK of brain ${ }_{\mathrm{ECF}}$ and brain ICF.

LeiCNS-PK3.0 allows the prediction of PK in the less accessible brain tissue and the potential PK changes associated with diseased conditions. LeiCNS-PK3.0 predictions are based explicitly on human CNS physiological parameters available from the literature, drug physicochemical parameters available from Drugbank database [26], and translated data from in vitro and preclinical studies. Thus, LeiCNS-PK3.0 overcomes the technical and ethical limitations of experimental approaches, such as the invasiveness of microdialysis, inability to differentiate parent drug and metabolite with imaging techniques, and the inaccurate lumbar CSF surrogacy to brain PK [12,102].

Paracellular passive diffusion across the BBB tight junction pores is especially critical for small, hydrophilic drugs, whose transport across the lipophilic membranes of BBB endothelial cells is limited, although this paracellular route represents about $0.004 \%$ of BBB surface area [12]. Increased passive transport via this route has been reported after BBB opening with hyperosmotic mannitol, where the brain exposure of atenolol [43] and methotrexate [103] increased by about 3- and 5-folds, respectively. BBB opening and widening of para ${ }_{\text {raduis }}$ after hyperosmotic mannitol were confirmed in the latter study using electron microscopy [103]. In CNS diseases, BBB permeability to drug transport across the paracellular route increases (Table 3). The impact of increased para radius $_{\text {on }}$ on passive transport across the BBB is rather dependent on the balance between passive transcellular and passive paracellular drug transport, the difference in $\mathrm{pH}$ between the compartments, and the contribution of active transporters to influx or efflux BBB transport (Table 2 and Table S1 in Supplementary Materials). An increase of passive paracellular transport will generally result in $\mathrm{Kp}_{\mathrm{uu}, \text { Ввв }}$ closer to unity [1]. Drugs that are heavily reliant on the transcellular route or on active transport are less sensitive to changes in para radius. $_{\text {. }}$ Drug physicochemical properties might also play a role, as the three drugs, whose BBB transport extent was affected, were lipophilic bases.

$\mathrm{PH}$ changes are relevant for drugs with $\mathrm{pk}_{\mathrm{a}}<9$ and/or $\mathrm{pk}_{\mathrm{b}}>3$, which ionize at the physiological $\mathrm{pH}$ range of 5-7.4, as the ionized drug species do not cross the transcellular route or cell membrane as assumed in LeiCNS-PK3.0 and are thus trapped in brain ICF and lysosomes or can escape brain ${ }_{\mathrm{ECF}}$ via the paracellular route and with ECF bulk flow [12]. A consequence of the trapping assumption is that the difference in $\mathrm{pH}$ across a membrane will result in unequal drug partitioning across the membrane. This phenomena has been overlooked in several studies where changes in brain $_{\mathrm{ECF}}$ PK due to traumatic brain injury were attributed to a reduction of active transport $[5,10]$ and increase para $a_{\text {radius }}[5,10,104]$, but not to $\mathrm{pH}_{\mathrm{ECF}}$. The results of our simulation strongly suggest that $\mathrm{pH}$ changes in CNS disease might play a bigger role in defining disease brain PK than previously conceived.

The impact on brain PK due to changes in para $_{\text {radius, }} \mathrm{pH}_{\mathrm{ECF}}$, and $\mathrm{pH}_{\mathrm{ICF}}$ during traumatic brain injury (TBI), Alzheimer's disease (AD), brain malignancies, cerebral ischemia, and epilepsy has been explored, as guided by LeiCNS-PK3.0 simulations. The pathophysiological changes of the three parameters in these CNS diseases are listed in Table 3. Quantitative information on para radius values in the different diseases are not always reported, and therefore, $\mathrm{BBB}$ permeability as an indirect measure of para radius $_{\text {was }}$ used.

Microdialysis studies in TBI patients have shown that brain ECF PK is different in the healthy versus injured brain tissue. In two independent studies, morphine PK was higher in the injured than in the healthy brain tissue of adult [104] and pediatric TBI patients [4]. In addition, cyclosporine brain ${ }_{\mathrm{ECF}} \mathrm{PK}$ might change in TBI patients [105]. In TBI patients, changes occur to $\mathrm{pH}_{\mathrm{ECF}}, \mathrm{pH}_{\mathrm{ECF}}$, and to para radius; the magnitude of change and time course of these parameters may differ according to trauma type: focal vs. diffuse TBI or close-head vs. open-head injury. In TBI patients, $\mathrm{pH}_{\mathrm{ECF}}$ and $\mathrm{pH}$ decline to 7 [22] and 6.9 [106], respectively. PH measurements in TBI mice suggest a biphasic change of $\mathrm{pH}$, which resolves after two hours, while in TBI patients, $\mathrm{pH}$ showed 
a resolution to normal values after about 10 days $[22,106]$. $\mathrm{PH}_{\text {ICF }}$ changes are of minor impact on traumatic brain $\mathrm{PK}$. However, $\mathrm{pH}_{\mathrm{ECF}}$ changes due to TBI might impact brain PK of drugs with $\mathrm{pk}_{\mathrm{a}}<8$ and $\mathrm{pk}_{\mathrm{b}}>6$, respectively. The BBB opening is another feature of TBI, as evidenced by the decrease in tight junction protein expression mainly claudin- 5 , occludin, and ZO-1 and an increase in BBB permeability to small and medium (0.1-10 kDa) and large molecules (up to $160 \mathrm{kDa}$ ) [107-109] in TBI mice. BBB opening and increased permeability resides up to the first 96 and $24 \mathrm{~h}$ post-injury for small and large molecules, respectively [107-109]. A wide range of CNS-acting medications are used to manage TBI patients including analgesics (e.g., acetaminophen, morphine), anticonvulsants (e.g., gabapentin and carbamazepin), neuroprotective agents (e.g., cyclosporine), etc. LeiCNSPK3.0 simulations at altered para radius $_{\text {and }} \mathrm{pH}_{\mathrm{ECF} / \mathrm{ICF}}$ have shown that the CNS PK of some of these drugs are potentially affected by these changes. An increase in para radius $_{\text {resulted }}$ in an increase in brain ${ }_{\mathrm{ECF}} \mathrm{C}_{\max }$ of morphine. Changes in $\mathrm{pH}_{\mathrm{ECF} / \mathrm{ICF}}$ might affect the PK of morphine $(\mathrm{pkb}=9.1)$ and gabapentin $\left(\mathrm{pk}_{\mathrm{a}}=4.6, \mathrm{pk}_{\mathrm{b}}=9.9\right)$. Combining the simulation results and literature findings on TBI pathophysiology and in vivo TBI PK suggests that

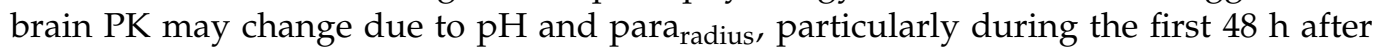
the injury.

Brain PK is potentially altered in epilepsy. Brain PK of phenytoin was lower in epileptic compared to control rats; the difference was accounted for by the increased p-gp expression in epileptic rats [110]. Brain PK of phenytoin increased following a seizure when p-gp expression was suppressed with nimodipine, implying a potential role of the BBB opening in altering phenytoin PK. Postmortem studies in rats and humans have demonstrated an increased BBB permeability to albumin and Evan's blue (Mwt $=69 \mathrm{kDa})$ following an epileptic seizure [111], which persisted in rats up to 1 week after the seizure [111]. Epileptic seizures result as well in a decrease in $\mathrm{pH}_{\mathrm{ECF}}$ by 0.5 units, which returns to normal values at a slower rate than $\mathrm{pH}_{\mathrm{ICF}}$, which declines by about $0.3 \mathrm{pH}$ units and is corrected within 20 min following seizure [112]. These changes in $\mathrm{pH}$ are expected to impact drugs with $\mathrm{pk}_{\mathrm{a}}<8$ and $\mathrm{pk}_{\mathrm{b}}>6$, respectively. Our simulations included antiepileptic drugs such as phenytoin, diazepam, carbamazepine, levetiracetam, and gabapentin. Of these drugs, only levetiracetam was sensitive to changes in para ${ }_{\text {radius }}$, while gabapentin (a zwitterion, $\mathrm{pk}_{\mathrm{a}}$ $=4.6$ and $\left.\mathrm{pk}_{\mathrm{b}}=9.9\right) \mathrm{PK}$ in brain $\mathrm{ICF}$ was sensitive to changes in $\mathrm{pH}_{\mathrm{ECF}}$. Phenytoin PK changes remains interesting, as despite experimental evidence of the importance of the passive transport route [110], LeiCNS-PK3.0 simulations showed no sensitivity to para radius $_{\text {s }}$ changes. It is worth mentioning that in vitro studies using human- and mouse-derived $p$-gp have concluded that phenytoin is actively transported in rodents but not in humans [113].

Glioma patients and sarcoma-laden rats showed higher methotrexate brain ECF $_{\text {PK }}$ compared to controls [7]. Cyclophosphamide brain ${ }_{\mathrm{ECF}} \mathrm{PK}$, on the contrary, was lower in tumor-bearing vs. non-tumor-bearing mice [31]. Brain tumors affect BBB permeability as demonstrated by the 8 -fold increase in para $a_{\text {radius }}$ in rats with a malignant glioma [114], which was measured with gadolinium-labeled nanoparticles of increasing size. In addition, the $\mathrm{pH}_{\mathrm{ECF}}$-to- $\mathrm{pH}_{\mathrm{ICF}}$ ratio is reversed in brain tumors, as $\mathrm{pH} \mathrm{ECF}_{\mathrm{EF}}$ decreases to 6.7, whereas $\mathrm{pH}_{\mathrm{ICF}}$ increases to $7.3[115,116]$. This will result in the change in PK and drug partitioning between brain $_{\mathrm{ECF}}$ and brain ${ }_{\mathrm{ICF}}$ [100], which is indicated by our $\mathrm{Kp}_{\text {uu,cell }}$ values (Figure 3 and Supplementary Figure S3), particularly for drugs with acidic and basic groups of $\mathrm{pk}_{\mathrm{a}}$ and $\mathrm{pk}_{\mathrm{b}}$ of $<8$ and $>6$, respectively. LeiCNS-PK3.0 simulations of the chemotherapeutic drugs, cyclophosphamide and methotrexate, showed a decline of $\mathrm{T}_{\max }$ due to increased para $_{\text {radius, }}$, while only methotrexate $\left(\mathrm{pk}_{\mathrm{a}}=3.4\right) \mathrm{PK}$ at brain $\mathrm{ECF}_{\mathrm{E}}$ and brain $\mathrm{IIF}_{\mathrm{ICF}} \mathrm{PK}$ was sensitive to $\mathrm{pH}_{\mathrm{ECF}}$ and $\mathrm{pH}_{\mathrm{ICF}}$ changes. 
Table 3. Pathophysiological changes of para ${ }_{\text {radius, }} \mathrm{pH}_{\mathrm{ECF}}$, and $\mathrm{pH}_{\mathrm{ICF}}$ in multiple CNS diseases.

\begin{tabular}{|c|c|c|c|}
\hline Disease & Parameter & Value & References \\
\hline \multirow{3}{*}{ Alzheimer's } & BBB permeability & $\leftrightarrow(86-150,000 \mathrm{Da})$ & [107] \\
\hline & $\mathrm{pH}_{\mathrm{ECF}}$ & \multirow{2}{*}{$\begin{array}{c}\downarrow \\
\downarrow(0.01 \mathrm{pH} \\
\text { unit/decade })\end{array}$} & \multirow{2}{*}{ [25] } \\
\hline & $\mathrm{pH}_{\mathrm{ICF}}$ & & \\
\hline \multirow{3}{*}{ Brain tumors } & para $_{\text {radius }}$ & $\uparrow(800 \%)$ & [114] \\
\hline & $\mathrm{pH}_{\mathrm{ECF}}$ & $\downarrow(0.6 \mathrm{pH}$ unit $)$ & {$[115,116]$} \\
\hline & $\mathrm{pH}_{\mathrm{ICF}}$ & $\uparrow(0.3 \mathrm{pH}$ unit $)$ & {$[115,116]$} \\
\hline \multirow{3}{*}{ TBI } & BBB permeability & $\uparrow($ up to $160,000 \mathrm{Da})$ & [107-109] \\
\hline & $\mathrm{pH}_{\mathrm{ECF}}$ & $\downarrow(0.3 \mathrm{pH}$ unit $)$ & [22] \\
\hline & $\mathrm{pH}_{\mathrm{ICF}}$ & $\downarrow(0.1 \mathrm{pH}$ unit $)$ & [106] \\
\hline \multirow{3}{*}{ Ischemia } & BBB permeability & $\uparrow($ up to $70,000 \mathrm{Da})$ & [117] \\
\hline & $\mathrm{pH}_{\mathrm{ECF}}$ & $\downarrow(1.4 \mathrm{pH}$ unit $)$ & [118] \\
\hline & $\mathrm{pH}_{\mathrm{ICF}}$ & $\downarrow$ (2 pH unit) & {$[23,24,119]$} \\
\hline \multirow{3}{*}{ Epilepsy } & BBB permeability & $\begin{array}{c}\uparrow(\text { albumin and up to } \\
70,000 \mathrm{Da})\end{array}$ & [111] \\
\hline & $\mathrm{pH}_{\mathrm{ECF}}$ & $\downarrow(0.5 \mathrm{pH}$ unit $)$ & [112] \\
\hline & $\mathrm{pH}_{\mathrm{ICF}}$ & $\downarrow(0.3 \mathrm{pH}$ unit $)$ & [112] \\
\hline
\end{tabular}

Profound changes in para ${ }_{\text {radius }}$ and $\mathrm{pH}_{\mathrm{ECF} / \mathrm{ICF}}$ during cerebral ischemia suggest a change in ischemic brain PK; however, evidence of such changes are not available in the literature. The BBB permeability of gadolinium $(\mathrm{Mwt}=590 \mathrm{Da})$ and Evan's blue increased in a rat model of cerebral ischemia-reperfusion injury, and this increase resided for 4 weeks for gadolinium and for 3 weeks for Evan's blue [117]. In addition, cerebral ischemia is associated with a 4-h severe brain acidosis, where the $\mathrm{pH}_{\mathrm{ECF}}$ declines to 5.9 [118], while $\mathrm{pH}_{\text {ICF }}$ declines to $5[23,24,119]$. This drastic $\mathrm{pH}$ change will result in altering the PK of both acidic $\left(\mathrm{pk}_{\mathrm{a}}<8\right)$ and basic $\left(\mathrm{pk}_{\mathrm{b}}>4\right)$ drugs.

Disease translation pharmacokinetic modeling is crucial for accurate predictions of drug effect, but it is challenging particularly for CNS diseases that are progressive, with yet unraveled pathophysiology mechanisms and scarce (pre)clinical data for model validation, not mentioning the ethical concerns in this sensitive yet critical research field. Thus, predicting a disease-specific PK at brain target sites requires a holistic approach such as PBPK modeling that accounts for both drug and (patho)physiology. In this manuscript, we applied our CNS PBPK model, LeiCNS-PK3.0, to predict the impact of altering one CNS parameter at a time on brain PK. LeiCNS-PK3.0 can also be used to predict a diseasespecific PK in different regions of the CNS. This will require accounting for all diseasespecific pathophysiological changes such as changes in tissue composition and non-specific binding [120], tissue volumes [121], active transporter expression and functionality [38], $\mathrm{pH}$ changes, CSF-related changes [12], etc. and their time course, i.e., deteriorating vs. healing. Such information is not always available from humans, and therefore, translating information on CNS pathophysiology from preclinical species is indispensable. Plasma PK acts as input to LeiCNS-PK3.0, and therefore, having the right plasma model from the disease population of interest is a crucial step to accurate CNS PK predictions. Plasma PK might change in CNS diseases compared to a healthy situation due to drug-drug interactions associated with concomitant drug administrations or due to declining liver and kidney functions as seen in elderly and AD patients.

\section{Conclusions}

With LeiCNS-PK3.0 simulations of CNS disease pathophysiology, we demonstrated that the BBB opening might increase the rate and extent of BBB passive transport and that a 
change of $\mathrm{pH}_{\mathrm{ECF}}$ and $\mathrm{pH}_{\mathrm{ICF}}$ can result in altered distribution of unbound drug in brain $\mathrm{ECF}_{\mathrm{F}}$ and brain ICF. The impact of those parameters on CNS PK should not be underestimated. It should be noted that our study conclusions remain limited to small drug molecules and may not extend to other drug classes as biologics.

Supplementary Materials: The following are available online at https:/ /www.mdpi.com/1999-492 3/13/1/95/s1, Figure S1. Detailed mathematical structure of LeiCNS-PK3.0; Figure S2. Simulated concentration-time profiles of all 46 drugs at physiological and pathophysiological values of CBF, para $_{\text {radius }}$, brain $_{\mathrm{ECF}}$ volume, $\mathrm{pH}_{\mathrm{ECF}}$, and $\mathrm{pH}_{\mathrm{ICF}}$; Figure $\mathrm{S}$. Heatmaps summarizing the effect of pathophysiological changes of $\mathrm{CBF}$, para radius $_{\text {, }}$ brain $\mathrm{ECF}_{\mathrm{EC}}$ volume, $\mathrm{pH}_{\mathrm{ECF}}$, and $\mathrm{pH}_{\mathrm{ICF}}$ on brain pharmacokinetics parameters: $C_{\max }, T_{\max }, A U C, K p_{u u, E C F}$, and $K p_{u u, c e l l} ;$ Table S1. Physicochemical properties and active transporter affinity of all 46 drugs; Table S2. Mean protein expression levels (in $\mathrm{fmol} / \mu \mathrm{g}$ total protein) of relevant transporters at the BBB.

Author Contributions: Conceptualization, M.A.A.S. and E.C.M.d.L.; methodology, M.A.A.S. and E.C.M.d.L.; formal analysis, M.A.A.S. and E.C.M.d.L.; investigation, M.A.A.S. and E.C.M.d.L.; writing—original draft preparation, M.A.A.S.; writing—review and editing, M.A.A.S. and E.C.M.d.L.; visualization, M.A.A.S.; supervision, E.C.M.d.L. All authors have read and agreed to the published version of the manuscript.

Funding: This research received no external funding.

Institutional Review Board Statement: Not applicable.

Informed Consent Statement: Not applicable.

Data Availability Statement: The data presented in this study are available on request from the corresponding author. The data are not publicly available due to privacy.

Conflicts of Interest: The authors declare no conflict of interest.

\section{References}

1. Hammarlund-Udenaes, M.; Fridén, M.; Syvänen, S.; Gupta, A. On the rate and extent of drug delivery to the brain. Pharm. Res. 2008, 25, 1737-1750. [CrossRef] [PubMed]

2. De Lange, E.C.M. The Physiological Characteristics and Transcytosis Mechanisms of the Blood-Brain Barrier (BBB). Curr. Pharm. Biotechnol. 2012, 13, 2319-2327. [CrossRef] [PubMed]

3. Loryan, I.; Sinha, V.; Mackie, C.; Van Peer, A.; Drinkenburg, W.H.; Vermeulen, A.; Heald, D.; Hammarlund-Udenaes, M.; Wassvik, C.M. Molecular properties determining unbound intracellular and extracellular brain exposure of CNS drug candidates. Mol. Pharm. 2015, 12, 520-532. [CrossRef] [PubMed]

4. Ketharanathan, N.; Yamamoto, Y.; Rohlwink, U.K.; Wildschut, E.D.; Mathôt, R.A.A.; De Lange, E.C.M.; De Wildt, S.N.; Argent, A.C.; Tibboel, D.; Figaji, A.A. Combining Brain Microdialysis and Translational Pharmacokinetic Modeling to Predict Drug Concentrations in Pediatric Severe Traumatic Brain Injury: The Next Step Toward Evidence-Based Pharmacotherapy? J. Neurotrauma 2019, 36, 111-117. [CrossRef]

5. Bouw, R.; Ederoth, P.; Lundberg, J.; Ungerstedt, U.; Nordström, C.-H.; Hammarlund-Udenaes, M. Increased blood-brain barrier permeability of morphine in a patient with severe brain lesions as determined by microdialysis. Acta Anaesthesiol. Scand. 2001, 45, 390-392. [CrossRef]

6. Löscher, W.; Potschka, H. Blood-brain barrier active efflux transporters: ATP-binding cassette gene family. NeuroRx 2005, 2, 86-98. [CrossRef]

7. Westerhout, J.; Van Den Berg, D.; Hartman, R.; Danhof, M.; De Lange, E.C.M. Prediction of methotrexate CNS distribution in different species-Influence of disease conditions. Eur. J. Pharm. Sci. 2014, 57, 11-24. [CrossRef]

8. Castaneda-Hernandez, G.; Hoyo-Vadillo, C.; Herrera, J.E. Differences in nifedipine concentration-effect relationship between capsule and slow release tablet administration. Int. J. Clin. Pharmacol. Ther. 1995, 33, 56-60.

9. Kuepfer, L.; Niederalt, C.; Wendl, T.; Schlender, J.F.; Willmann, S.; Lippert, J.; Block, M.; Eissing, T.; Teutonico, D. Applied Concepts in PBPK Modeling: How to Build a PBPK/PD Model. CPT Pharmacomet. Syst. Pharmacol. 2016, 5, 516-531. [CrossRef]

10. Yamamoto, Y.; Välitalo, P.A.; Wong, Y.C.; Huntjens, D.R.; Proost, J.H.; Vermeulen, A.; Krauwinkel, W.; Beukers, M.W.; Kokki, H.; Kokki, M.; et al. Prediction of human CNS pharmacokinetics using a physiologically-based pharmacokinetic modeling approach. Eur. J. Pharm. Sci. 2018, 112, 168-179. [CrossRef]

11. Westerhout, J.; Ploeger, B.; Smeets, J.; Danhof, M.; De Lange, E.C.M. Physiologically based pharmacokinetic modeling to investigate regional brain distribution kinetics in rats. AAPS J. 2012, 14, 543-553. [CrossRef] [PubMed]

12. Saleh, M.A.A.; Loo, C.F.; Elassaiss-Schaap, J.; De Lange, E.C.M. Lumbar cerebrospinal fluid-to-Brain extracellular fluid surrogacy is context-specific: Insights from LeiCNS-PK3.0 simulations. J Pharmacokinet Pharmacodyn. Under review. 
13. Yamamoto, Y.; Välitalo, P.; Huntjens, D.; Proost, J.; Vermeulen, A.; Krauwinkel, W.; Beukers, M.; van den Berg, D.; Hartman, R.; Wong, Y.; et al. Predicting drug concentration-time profiles in multiple relevant CNS compartments using a comprehensive physiologically-based pharmacokinetic model. CPT Pharmacomet. Syst. Pharmacol. 2017, 6, 765-777. [CrossRef] [PubMed]

14. Jessen, N.A.; Munk, A.S.F.; Lundgaard, I.; Nedergaard, M. The Glymphatic System: A Beginner's Guide. Neurochem. Res. 2015, 40, 2583-2599. [CrossRef] [PubMed]

15. Syková, E. The extracellular space in the CNS: Its regulation, volume and geometry in normal and pathological neuronal function. Neuroscientist 1997, 3, 28-41. [CrossRef]

16. Yamazaki, Y.; Shinohara, M.; Shinohara, M.; Yamazaki, A.; Murray, M.E.; Liesinger, A.M.; Heckman, M.G.; Lesser, E.R.; Parisi, J.E.; Petersen, R.C.; et al. Selective loss of cortical endothelial tight junction proteins during Alzheimer's disease progression. Brain 2019, 142, 1077-1092. [CrossRef] [PubMed]

17. Costea, L.; Mészáros; Bauer, H.; Bauer, H.C.; Traweger, A.; Wilhelm, I.; Farkas, A.E.; Krizbai, I.A. The blood-brain barrier and its intercellular junctions in age-related brain disorders. Int. J. Mol. Sci. 2019, 20, 5472. [CrossRef]

18. Logsdon, A.F.; Meabon, J.S.; Cline, M.M.; Bullock, K.M.; Raskind, M.A.; Peskind, E.R.; Banks, W.A.; Cook, D.G. Blast exposure elicits blood-brain barrier disruption and repair mediated by tight junction integrity and nitric oxide dependent processes. Sci. Rep. 2018, 8, 1-13. [CrossRef]

19. Roher, A.E.; Debbins, J.P.; Malek-Ahmadi, M.; Chen, K.; Pipe, J.G.; Maze, S.; Belden, C.; Maarouf, C.L.; Thiyyagura, P.; Mo, H.; et al. Cerebral blood flow in Alzheimer's disease. Vasc. Health Risk Manag. 2012, 8, 599-611. [CrossRef]

20. van Es, A.C.G.M.; van der Grond, J.; ten Dam, V.H.; de Craen, A.J.M.; Blauw, G.J.; Westendorp, R.G.J.; Admiraal-Behloul, F.; van Buchem, M.A. Associations between total cerebral blood flow and age related changes of the brain. PLoS ONE 2010, 5 , e9825. [CrossRef]

21. Laitio, R.M.; Kaisti, K.K.; Langsjö, J.W.; Aalto, S.; Salmi, E.; Maksimow, A.; Aantaa, R.; Oikonen, V.; Sipila, H.; Parkkola, R.; et al. Effects of xenon anesthesia on cerebral blood flow in neurosurgical humans. Anesthesiology 2007, 106, 1128-1133. [CrossRef] [PubMed]

22. Gupta, A.K.; Zygun, D.A.; Johnston, A.J.; Steiner, L.A.; Al-rawi, P.G.; Chatfield, D.O.T.; Shepherd, E.; Kirkpatrick, P.J.; Hutchinson, P.J.; Menon, D.K. Extracellular Brain pH and Outcome following Severe Traumatic Brain Injury. J. Neurotrauma 2004, 21, 678-684. [CrossRef] [PubMed]

23. Remzso, G.; Németh, J.; Varga, V.; Kovács, V.; TóthSzuki, V.; Kaila, K.; Voipio, J.; Domoki, F. Brain interstitial pH changes in the subacute phase of hypoxic-ischemic encephalopathy in newborn pigs. PLoS ONE 2020, 15, e0240643. [CrossRef]

24. Rehncrona, S. Brain acidosis. Ann. Emerg. Med. 1985, 14, 770-776. [CrossRef]

25. Lyros, E.; Ragoschke-Schumm, A.; Kostopoulos, P.; Sehr, A.; Backens, M.; Kalampokini, S.; Decker, Y.; Lesmeister, M.; Liu, Y.; Reith, W.; et al. Normal brain aging and Alzheimer's disease are associated with lower cerebral pH: An in vivo histidine 1H-MR spectroscopy study. Neurobiol. Aging 2020, 87, 60-69. [CrossRef] [PubMed]

26. Wishart, D.S.; Feunang, Y.D.; Guo, A.C.; Lo, E.J.; Marcu, A.; Grant, J.R.; Sajed, T.; Johnson, D.; Li, C.; Sayeeda, Z.; et al. DrugBank 5.0: A major update to the DrugBank database for 2018. Nucleic Acids Res. 2017, 46, D1074-D1082. [CrossRef] [PubMed]

27. Manchester, J.; Walkup, G.; Rivin, O.; You, Z. Evaluation of pka Estimation Methods on 211 Druglike Compounds. J. Chem. Inf. Model. 2010, 50, 565-571. [CrossRef] [PubMed]

28. Mannhold, R.; Poda, G.I.; Ostermann, C.; Tetko, I.V. Calculation of Molecular Lipophilicity: State-of-the-Art and Comparison of LogP Methods on More Than 96,000 Compounds. J. Pharm. Sci. 2009, 98, 861-893. [CrossRef]

29. Summerfield, S.G.; Read, K.; Begley, D.J.; Obradovic, T.; Hidalgo, I.J.; Coggon, S.; Lewis, A.V.; Porter, R.A.; Jeffrey, P. Central Nervous System Drug Disposition: The Relationship between in Situ Brain Permeability and Brain Free Fraction. J. Pharmacol. Exp. Ther. 2007, 322, 205-213. [CrossRef]

30. Nagaya, Y.; Nozaki, Y.; Takenaka, O.; Watari, R.; Kusano, K.; Yoshimura, T.; Kusuhara, H. Investigation of utility of cerebrospinal fluid drug concentration as a surrogate for interstitial fluid concentration using microdialysis coupled with cisternal cerebrospinal fluid sampling in wild-type and Mdr1a(-/-) rats. Drug Metab. Pharmacokinet. 2016, 31, 57-66. [CrossRef]

31. Campagne, O.; Davis, A.; Zhong, B.; Nair, S.; Haberman, V.; Patel, Y.T.; Janke, L.; Roussel, M.F.; Stewart, C.F. CNS Penetration of Cyclophosphamide and Metabolites in Mice Bearing Group 3 Medulloblastoma and Non-tumor Bearing Mice. J. Pharm. Pharm. Sci. 2019, 22, 612-629. [CrossRef] [PubMed]

32. Al-Majdoub, Z.M.; Al Feteisi, H.; Achour, B.; Warwood, S.; Neuhoff, S.; Rostami-Hodjegan, A.; Barber, J. Proteomic Quantification of Human Blood-Brain Barrier SLC and ABC Transporters in Healthy Individuals and Dementia Patients. Mol. Pharm. 2019. [CrossRef] [PubMed]

33. Al Feteisi, H.; Al-Majdoub, Z.M.; Achour, B.; Couto, N.; Rostami-Hodjegan, A.; Barber, J. Identification and quantification of blood-brain barrier transporters in isolated rat brain microvessels. J. Neurochem. 2018, 146, 670-685. [CrossRef]

34. Uchida, Y.; Ohtsuki, S.; Katsukura, Y.; Ikeda, C.; Suzuki, T.; Kamiie, J.; Terasaki, T. Quantitative targeted absolute proteomics of human blood-brain barrier transporters and receptors. J. Neurochem. 2011, 117, 333-345. [CrossRef] [PubMed]

35. Hoshi, Y.; Uchida, Y.; Tachikawa, M.; Inoue, T.; Ohtsuki, S.; Terasaki, T. Quantitative Atlas of Blood-Brain Barrier Transporters, Receptors, and Tight Junction Proteins in Rats and Common Marmoset. J. Pharm. Sci. 2013, 102, 3343-3355. [CrossRef]

36. Shawahna, R.; Uchida, Y.; Declèves, X.; Ohtsuki, S.; Yousif, S.; Dauchy, S.; Jacob, A.; Chassoux, F.; Daumas-Duport, C.; Couraud, P.O.; et al. Transcriptomic and quantitative proteomic analysis of transporters and drug metabolizing enzymes in freshly isolated human brain microvessels. Mol. Pharm. 2011, 8, 1332-1341. [CrossRef] 
37. Kodaira, H.; Kusuhara, H.; Fuse, E.; Ushiki, J.; Sugiyama, Y. Quantitative investigation of the brain-to-cerebrospinal fluid unbound drug concentration ratio under steady-state conditions in rats using a pharmacokinetic model and scaling factors for active efflux transporters. Drug Metab. Dispos. 2014, 42, 983-989. [CrossRef]

38. De Lange, E.C.M.; vd Berg, D.J.; Bellanti, F.; Voskuyl, R.A.; Syvänen, S. P-glycoprotein protein expression versus functionality at the blood-brain barrier using immunohistochemistry, microdialysis and mathematical modeling. Eur. J. Pharm. Sci. 2018, 124, 61-70. [CrossRef]

39. Chu, X.; Bleasby, K.; Evers, R. Species differences in drug transporters and implications for translating preclinical findings to humans. Expert Opin. Drug Metab. Toxicol. 2013, 9, 237-252. [CrossRef]

40. Li, M.; Yuan, H.; Li, N.; Song, G.; Zheng, Y.; Baratta, M.; Hua, F.; Thurston, A.; Wang, J.; Lai, Y. Identification of interspecies difference in efflux transporters of hepatocytes from dog, rat, monkey and human. Eur. J. Pharm. Sci. 2008, 35, 114-126. [CrossRef]

41. Booth-Genthe, C.L.; Louie, S.W.; Carlini, E.J.; Li, B.; Leake, B.F.; Eisenhandler, R.; Hochman, J.H.; Mei, Q.; Kim, R.B.; Rushmore, T.H.; et al. Development and characterization of LLC-PK1 cells containing Sprague-Dawley rat Abcb1a (Mdr1a): Comparison of rat P-glycoprotein transport to human and mouse. J. Pharmacol. Toxicol. Methods 2006, 54, 78-89. [CrossRef] [PubMed]

42. Nordström, C.H.; Koskinen, L.O.; Olivecrona, M. Aspects on the physiological and biochemical foundations of neurocritical care. Front. Neurol. 2017, 8, 1-24. [CrossRef] [PubMed]

43. De Lange, E.C.M.; Hesselink, M.B.; Danhof, M.; de Boer, A.G.; Breimer, D.D. The Use of Intracerebral Microdialysis to Determine Changes in Blood-Brain Barrier Transport Characteristics. Pharm. Res. 1995, 12, 129-133. [CrossRef] [PubMed]

44. Arieff, A.I.; Kerian, A.; Massry, S.G.; DeLima, J. Intracellular pH of brain: Alterations in acute respiratory acidosis and alkalosis. Am. J. Physiol. 1976, 230, 804-812. [CrossRef]

45. Fidler, M.; Hallow, M.; Wilkins, J.; Wang, W. RxODE: Facilities for Simulating from ODE-Based Models. R package version 0.7.2-5. 2018. Available online: https:/ /CRAN.R-project.org/package=RxODE.

46. R Core Team. R: A Language and Environment for Statistical Computing; R Foundation for Statistical Computing: Vienna, Austria, 2019.

47. Courchesne, E.; Chisum, H.J.; Townsend, J.; Cowles, A.; Covington, J.; Egaas, B.; Harwood, M.; Hinds, S.; Press, G.A. Normal Brain Development and Aging: Quantitative Analysis at in Vivo MR Imaging in Healthy Volunteers. Radiology 2000, 216, 672-682. [CrossRef]

48. Filipek, P.A.; Richelme, C.; Kennedy, D.N.; Caviness, V.S. The Young Adult Human Brain: An MRI-based Morphometric Analysis. Cereb. Cortex 1994, 4, 344-360. [CrossRef]

49. Gur, R.C.; Mozley, P.D.; Resnick, S.M.; Gottlieb, G.L.; Kohn, M.; Zimmerman, R.A.; Herman, G.T.; Atlas, S.; Grossman, R.; Berretta, D. Gender differences in age effect on brain atrophy measured by magnetic resonance imaging. Proc. Natl. Acad. Sci. USA 1991, 88, 2845-2849. [CrossRef]

50. Peters, M.; Jäncke, L.; Staiger, J.F.; Schlaug, G.; Huang, Y.; Steinmetz, H. Unsolved Problems in Comparing Brain Sizes in Homo Sapiens. Brain Cogn. 1998, 37, 254-285. [CrossRef]

51. Lei, Y.; Han, H.; Yuan, F.; Javeed, A.; Zhao, Y. The brain interstitial system: Anatomy, modeling, in vivo measurement, and applications. Prog. Neurobiol. 2017, 157, 230-246. [CrossRef]

52. Miyajima, M.; Arai, H. Evaluation of the Production and Absorption of Cerebrospinal Fluid. Neurol. Med. Chir. (Tokyo) 2015, 55, 647-656. [CrossRef]

53. Nicholson, C. Diffusion and related transport mechanisms in brain tissue. Rep. Prog. Phys. 2001, 64, 815-884. [CrossRef]

54. Nicholson, C.; Kamali-Zare, P.; Tao, L. Brain Extracellular Space as a Diffusion Barrier. Comput. Vis. Sci. 2011, 14, 309-325. [CrossRef] [PubMed]

55. Thorne, R.G.; Hrabětová, S.; Nicholson, C. Diffusion of Epidermal Growth Factor in Rat Brain Extracellular Space Measured by Integrative Optical Imaging. J. Neurophysiol. 2004, 92, 3471-3481. [CrossRef] [PubMed]

56. Weibel, E.R.; Stäubli, W.; Gnägi, H.R.; Hess, F.A. Correlated Morphometric and Biochemical Studies on the Liver Cell: I. Morphometric Model, Stereologic Methods, and Normal Morphometric Data for Rat Liver. J. Cell Biol. 1969, $42,68-91$. [CrossRef] [PubMed]

57. Brown, R.P.; Delp, M.D.; Lindstedt, S.L.; Rhomberg, L.R.; Beliles, R.P. Physiological Parameter Values for Physiologically Based Pharmacokinetic Models. Toxicol. Ind. Health 1997, 13, 407-484. [CrossRef]

58. Hu, Z.-Y.; Lu, J.; Zhao, Y. A physiologically based pharmacokinetic model of alvespimycin in mice and extrapolation to rats and humans. Br. J. Pharmacol. 2014, 171, 2778-2789. [CrossRef]

59. Allen, J.S.; Damasio, H.; Grabowski, T.J. Normal neuroanatomical variation in the human brain: An MRI-volumetric study. Am. J. Phys. Anthropol. 2002, 118, 341-358. [CrossRef]

60. Barra, V.; Frenoux, E.; Boire, J.-Y. Automatic volumetric measurement of lateral ventricles on magnetic resonance images with correction of partial volume effects. J. Magn. Reson. Imaging 2002, 15, 16-22. [CrossRef]

61. Erdogan, A.L.I.R.; Dane, S.; Aydin, M.D.; Özdikici, M.; Diyarbakirli, S. Sex and Handedness Differences in Size of Cerebral Ventricles of Normal Subjects. Int. J. Neurosci. 2004, 114, 67-73. [CrossRef]

62. Lamers, M.; Klein, W.; Góraj, B. Normal Values of Ventricular Volume and Cerebrospinal Fluid (CSF) Circulation in Healthy Subjects. Available online: https://posterng.netkey.at/esr/viewing/index.php?module=viewing_poster\&doi=10.1594/ecr201 0/C-2729 (accessed on 1 November 2020). 
63. Trimarchi, F.; Bramanti, P.; Marino, S.; Milardi, D.; Di Mauro, D.; Ielitro, G.; Valenti, B.; Vaccarino, G.; Milazzo, C.; Cutroneo, G. MRI 3D lateral cerebral ventricles in living humans: Morphological and morphometrical age-, gender-related preliminary study. Anat. Sci. Int. 2013, 88, 61-69. [CrossRef]

64. Whitney, N.; Sun, H.; Pollock, J.M.; Ross, D.A. The human foramen magnum-Normal anatomy of the cisterna magna in adults. Neuroradiology 2013, 55, 1333-1339. [CrossRef]

65. Conn, P.M. Neuroscience in Medicine; Springer Science \& Business Media: Totowa, NJ, USA, 2003; ISBN 978-1-59259-371-2.

66. Parviz, J. Surgical Anatomy of the Head and Neck; Harvard University Press: Cambridge, MA, USA, 2011; ISBN 978-0-674-41783-0.

67. Sakka, L.; Coll, G.; Chazal, J. Anatomy and physiology of cerebrospinal fluid. Eur. Ann. Otorhinolaryngol. Head Neck Dis. 2011, 128, 309-316. [CrossRef]

68. Lassen, N.A. Normal Average Value of Cerebral Blood Flow in Younger Adults is $50 \mathrm{~mL} / 100 \mathrm{~g} / \mathrm{min}$. J. Cereb. Blood Flow Metab. 1985, 5, 347-349. [CrossRef]

69. Madsen, P.L.; Holm, S.; Herning, M.; Lassen, N.A. Average Blood Flow and Oxygen Uptake in the Human Brain during Resting Wakefulness: A Critical Appraisal of the Kety-Schmidt Technique. J. Cereb. Blood Flow Metab. 1993, 13, 646-655. [CrossRef] [PubMed]

70. Pascoe, M.J.; Melzer, T.R.; Horwood, L.J.; Woodward, L.J.; Darlow, B.A. Altered grey matter volume, perfusion and white matter integrity in very low birthweight adults. NeuroImage Clin. 2019, 22, 101780. [CrossRef] [PubMed]

71. Kimelberg, H.K. Water homeostasis in the brain: Basic concepts. Neuroscience 2004, 129, 851-860. [CrossRef] [PubMed]

72. Cserr, H.F. Physiology of the choroid plexus. Physiol. Rev. 1971. [CrossRef] [PubMed]

73. Edsbagge, M.; Tisell, M.; Jacobsson, L.; Wikkelso, C. Spinal CSF absorption in healthy individuals. Am. J. Physiol. Regul. Integr. Comp. Physiol. 2004, 287, R1450-R1455. [CrossRef]

74. Lumenta, C.B.; Di Rocco, C.; Haase, J.; Mooij, J.J.A. Neurosurgery; Springer Science \& Business Media: Berlin/Heidelberg, Germany, 2009; ISBN 978-3-540-79565-0.

75. Wright, E.M. Transport processes in the formation of the cerebrospinal fluid. In Reviews of Physiology, Biochemistry and Pharmacology; Springer: Berlin/Heidelberg, Germany, 1978; Volume 83, pp. 1-34. ISBN 978-3-540-35785-8.

76. Abbott, N.J.; Patabendige, A.A.K.; Dolman, D.E.M.; Yusof, S.R.; Begley, D.J. Structure and function of the blood-brain barrier. Neurobiol. Dis. 2010, 37, 13-25. [CrossRef]

77. Crone, C. The Permeability of Capillaries in Various Organs as Determined by Use of the 'Indicator Diffusion' Method. Acta Physiol. Scand. 1963, 58, 292-305. [CrossRef]

78. Di, L.; Kerns, E.H. Blood-Brain Barrier in Drug Discovery: Optimizing Brain Exposure of CNS Drugs and Minimizing Brain Side Effects for Peripheral Drugs; John Wiley \& Sons: Hoboken, NJ, USA, 2015; ISBN 978-1-118-78835-6.

79. Gao, H.; Gao, X. Brain Targeted Drug Delivery Systems: A Focus on Nanotechnology and Nanoparticulates; Academic Press: Cambridge, MA, USA, 2018; ISBN 978-0-12-814002-4.

80. Gross, P.M.; Sposito, N.M.; Pettersen, S.E.; Fenstermacher, J.D. Differences in Function and Structure of the Capillary Endothelium in Gray Matter, White Matter and a Circumventricular Organ of Rat Brain. J. Vasc. Res. 1986, 23, 261-270. [CrossRef] [PubMed]

81. Pardridge, W.M. The blood-brain barrier: Bottleneck in brain drug development. NeuroRx 2005, 2, 3-14. [CrossRef] [PubMed]

82. Redzic, Z. Molecular biology of the blood-brain and the blood-cerebrospinal fluid barriers: Similarities and differences. Fluids Barriers CNS 2011, 8, 3. [CrossRef] [PubMed]

83. Sharma, H.S. Blood-Spinal Cord and Brain Barriers in Health and Disease; Elsevier: Amsterdam, The Netherlands, 2003; ISBN 978-0-08-052822-9.

84. Wong, A.D.; Ye, M.; Levy, A.F.; Rothstein, J.D.; Bergles, D.E.; Searson, P.C. The blood-brain barrier: An engineering perspective. Front. Neuroeng. 2013, 6, 1-22. [CrossRef]

85. Pardridge, W.M. CSF, blood-brain barrier, and brain drug delivery. Expert Opin. Drug Deliv. 2016, 13, 963-975. [CrossRef]

86. Spector, R.; Keep, R.F.; Snodgrass, S.R.; Smith, Q.R.; Johanson, C.E. A balanced view of choroid plexus structure and function: Focus on adult humans. Exp. Neurol. 2015, 267, 78-86. [CrossRef]

87. Andrade-Moraes, C.H.; Oliveira-Pinto, A.V.; Castro-Fonseca, E.; da Silva, C.G.; Guimarães, D.M.; Szczupak, D.; Parente-Bruno, D.R.; Carvalho, L.R.B.; Polichiso, L.; Gomes, B.V.; et al. Cell number changes in Alzheimer's disease relate to dementia, not to plaques and tangles. Brain 2013, 136, 3738-3752. [CrossRef]

88. Azevedo, F.A.C.; Carvalho, L.R.B.; Grinberg, L.T.; Farfel, J.M.; Ferretti, R.E.L.; Leite, R.E.P.; Filho, W.J.; Lent, R.; Herculano-Houzel, S. Equal numbers of neuronal and nonneuronal cells make the human brain an isometrically scaled-up primate brain. J. Comp Neurol. 2009, 513, 532-541. [CrossRef]

89. Bakker, A.C.; Webster, P.; Jacob, W.A.; Andrews, N.W. Homotypic fusion between aggregated lysosomes triggered by elevated $\left[\mathrm{Ca}^{2+}\right]$ i in fibroblasts. J. Cell Sci. 1997, 110, 2227-2238.

90. Bandyopadhyay, D.; Cyphersmith, A.; Zapata, J.A.; Kim, Y.J.; Payne, C.K. Lysosome transport as a function of lysosome diameter. PLoS ONE 2014, 9, e86847. [CrossRef]

91. Demers-Lamarche, J.; Guillebaud, G.; Tlili, M.; Todkar, K.; Bélanger, N.; Grondin, M.; Nguyen, A.P.; Michel, J.; Germain, M. Loss of Mitochondrial Function Impairs Lysosomes. J. Biol. Chem. 2016, 291, 10263-10276. [CrossRef] [PubMed]

92. Rahman, Y.E. Electron microscopy of lysosome-rich fractions from rat thymus isolated by density-gradient centrifugation before and after whole-body x-irradiation. J. Cell Biol. 1962, 13, 253-260. [CrossRef] [PubMed]

93. Xu, H.; Ren, D. Lysosomal Physiology. Annu. Rev. Physiol. 2015, 77, 57-80. [CrossRef] 
94. Cornford, M.E.; Landaw, E.M.; Hyman, S.; Cornford, E.M.; Delgado-Escueta, A.V. Interictal Seizure Resections Show Two Configurations of Endothelial Glut1 Glucose Transporter in the Human Blood-Brain Barrier. J. Cereb. Blood Flow Metab. 1998, 18, 26-42. [CrossRef] [PubMed]

95. Sarin, H. Physiologic upper limits of pore size of different blood capillary types and another perspective on the dual pore theory of microvascular permeability. J. Angiogenes. Res. 2010, 2, 14. [CrossRef]

96. Monteiro, J.N.; Goraksha, S.U. 'ROSE concept' of fluid management: Relevance in neuroanaesthesia and neurocritical care. J. Neuroanaesth. Crit. Care 2017, 4, 10-16. [CrossRef]

97. Haas, T.L.; Duling, B.R. Morphology Favors an Endothelial Cell Pathway for Longitudinal Conduction within Arterioles. Microvasc. Res. 1997, 53, 113-120. [CrossRef]

98. Schulze, C.; Firth, J.A. Interendothelial junctions during blood-brain barrier development in the rat: Morphological changes at the level of individual tight junctional contacts. Dev. Brain Res. 1992, 69, 85-95. [CrossRef]

99. Atherton, J.C. Acid-base balance: Maintenance of plasma pH. Anaesth. Intensive Care Med. 2003, 4, 419-422. [CrossRef]

100. Fridén, M.; Bergström, F.; Wan, H.; Rehngren, M.; Ahlin, G.; Hammarlund-Udenaes, M.; Bredberg, U. Measurement of unbound drug exposure in brain: Modeling of $\mathrm{pH}$ partitioning explains diverging results between the brain slice and brain homogenate methods. Drug Metab. Dispos. 2011, 39, 353-362. [CrossRef]

101. Siesjö, B.K. Symposium on acid-base homeostasis. The regulation of cerebrospinal fluid pH. Kidney Int. 1972, 1, 360-374. [CrossRef] [PubMed]

102. De Lange, E.C.M. Utility of CSF in translational neuroscience. J. Pharmacokinet. Pharmacodyn. 2013, 40, 315-326. [CrossRef] [PubMed]

103. Cosolo, W.C.; Martinello, P.; Louis, W.J.; Christophidis, N. Blood-brain barrier disruption using mannitol: Time course and electron microscopy studies. Am. J. Physiol. Regul. Integr. Comp. Physiol. 1989, 256, 443-447. [CrossRef]

104. Ederoth, P.; Tunblad, K.; Bouw, R.; Lundberg, C.J.F.; Ungerstedt, U.; Nordström, C.H.; Hammarlund-Udenaes, M. Blood-brain barrier transport of morphine in patients with severe brain trauma. Br. J. Clin. Pharmacol. 2004, 57, 427-435. [CrossRef] [PubMed]

105. Brophy, G.M.; Mazzeo, A.T.; Brar, S.; Alves, O.L.; Bunnell, K.; Gilman, C.; Karnes, T.; Hayes, R.L.; Bullock, R. Exposure of Cyclosporin A in Whole Blood, Cerebral Spinal Fluid, and Brain Extracellular Fluid Dialysate in Adults with Traumatic Brain Injury. J. Neurotrauma 2013, 30, 1484-1489. [CrossRef]

106. Vink, R.; McIntosh, T.K.; Weiner, M.W.; Faden, A.I. Effects of traumatic brain injury on cerebral high-energy phosphates and pH: A 31P magnetic resonance spectroscopy study. J. Cereb. Blood Flow Metab. 1987, 7, 563-571. [CrossRef]

107. Lochhead, J.J.; Yang, J.; Ronaldson, P.T.; Davis, T.P. Structure, Function, and Regulation of the Blood-Brain Barrier Tight Junction in Central Nervous System Disorders. Front. Physiol. 2020, 11. [CrossRef]

108. Hue, C.D.; Cho, F.S.; Cao, S.; Nicholls, R.E.; Vogel, E.W.; Sibindi, C.; Arancio, O.; Dale Bass, C.R.; Meaney, D.F.; Morrison, B. Time Course and Size of Blood-Brain Barrier Opening in a Mouse Model of Blast-Induced Traumatic Brain Injury. J. Neurotrauma 2016, 33, 1202-1211. [CrossRef]

109. Readnower, R.D.; Chavko, M.; Adeeb, S.; Conroy, M.D.; Pauly, J.R.; McCarron, R.M.; Sullivan, P.G. Increase in Blood Brain Barrier Permeability, Oxidative Stress, and Activated Microglia in a Rat Model of Blast Induced Traumatic Brain Injury. J. Neurosci. Res. 2010, 88, 3530-3539. [CrossRef]

110. Höcht, C.; Lazarowski, A.; Gonzalez, N.N.; Auzmendi, J.; Opezzo, J.A.W.; Bramuglia, G.F.; Taira, C.A.; Girardi, E. Nimodipine restores the altered hippocampal phenytoin pharmacokinetics in a refractory epileptic model. Neurosci. Lett. 2007, 413, 168-172. [CrossRef]

111. Van Vliet, E.A.; Araújo, S.D.C.; Redeker, S.; Van Schaik, R.; Aronica, E.; Gorter, J.A. Blood-brain barrier leakage may lead to progression of temporal lobe epilepsy. Brain 2007, 130, 521-534. [CrossRef] [PubMed]

112. Siesjo, B.K.; von Hanwehr, R.; Nergelius, G.; Nevander, G.; Ingvar, M. Extra- and intracellular pH in the brain during seizures and in the recovery period following the arrest of seizure activity. J. Cereb. Blood Flow Metab. 1985, 5, 47-57. [CrossRef] [PubMed]

113. Baltes, S.; Gastens, A.M.; Fedrowitz, M.; Potschka, H.; Kaever, V.; Löscher, W. Differences in the transport of the antiepileptic drugs phenytoin, levetiracetam and carbamazepine by human and mouse P-glycoprotein. Neuropharmacology 2007, 52, 333-346. [CrossRef] [PubMed]

114. Sarin, H.; Kanevsky, A.S.; Wu, H.; Brimacombe, K.R.; Fung, S.H.; Sousa, A.A.; Auh, S.; Wilson, C.M.; Sharma, K.; Aronova, M.A.; et al. Effective transvascular delivery of nanoparticles across the blood-brain tumor barrier into malignant glioma cells. J. Transl. Med. 2008, 6, 1-15. [CrossRef]

115. Lim, H.; Albatany, M.; Martínez-Santiesteban, F.; Bartha, R.; Scholl, T.J. Longitudinal Measurements of Intra- and Extracellular $\mathrm{pH}$ Gradient in a Rat Model of Glioma. Tomography 2018, 4, 46-54. [CrossRef]

116. Hao, G.; Xu, Z.P.; Li, L. Manipulating extracellular tumour pH: An effective target for cancer therapy. RSC Adv. 2018, 8, 22182-22192. [CrossRef]

117. Strbian, D.; Durukan, A.; Pitkonen, M.; Marinkovic, I.; Tatlisumak, E.; Pedrono, E.; Abo-Ramadan, U.; Tatlisumak, T. The blood-brain barrier is continuously open for several weeks following transient focal cerebral ischemia. Neuroscience 2008, 153, 175-181. [CrossRef]

118. Nedergaard, M.; Kraig, R.P.; Tanabe, J.; Pulsinelli, W.A. Dynamics of interstitial and intracellular pH in evolving brain infarct. Am. J. Physiol. 1991, 260, R581-R588. [CrossRef] 
119. Hurn, P.D.; Traystman, R.J. pH-Associated brain injury in cerebral ischemia and circulatory arrest. J. Intensive Care Med. 1996, 11, 205-218. [CrossRef]

120. Gustafsson, S.; Sehlin, D.; Lampa, E.; Hammarlund-Udenaes, M.; Loryan, I. Heterogeneous drug tissue binding in brain regions of rats, Alzheimer's patients and controls: Impact on translational drug development. Sci. Rep. 2019, 9, 5308. [CrossRef]

121. Fjell, A.M.; McEvoy, L.; Holland, D.; Dale, A.M.; Walhovd, K.B. Brain changes in older adults at very low risk for Alzheimer's disease. J. Neurosci. 2013, 33, 8237-8242. [CrossRef] [PubMed] 